\title{
Analysis of Teaching Reform of Tourism Management Major in Colleges and Universities Under "Internet + "
}

Ying Zhang

Taishan University, Taian 271000, Shandong, China.

Abstract: With the rapid development of information technology, information education has been realized in all stages of education and teaching in our country, and it has very good teaching effects. This article discusses and analyzes the current situation of the teaching of tourism management in colleges and universities under the environment of "Internet + " from multiple angles, and proposes some reform measures for teaching methods in response to the problems reflected, aiming to better improve the teaching quality of tourism management in colleges and universities.

Keywords: "Internet+"; University Tourism Management; Teaching Reform; Analysis

In recent years, Internet information technology has been effectively used in multiple stages of education and teaching, and university tourism management teaching is also one of them. Tourism management is a very typical and important subject in university management. In the actual teaching process, teachers can use Internet information technology to make certain improvements to traditional teaching methods and effectively improve the quality of tourism management teaching. However, after a period of teaching adaptation, there are still some problems in the teaching of tourism management in colleges and universities under the "Internet + " environment. Teachers need to address these problems and research ways to improve teaching quality, and then continuously optimize the teaching effect of tourism management.

\section{The teaching status of tourism management major in colleges and universities under the "Internet +" environment}

\subsection{The teacher's teaching thinking is too rigid}

Affected by the traditional test-oriented education, although teachers have made certain changes in the specific teaching methods in the "Internet +" environment, the basic teaching thinking still maintains the characteristics of test-oriented teaching, which is still "cracking duck" in essence. Indoctrination" traditional teaching philosophy. This kind of passive learning teaching method seriously hinders the improvement of students' thinking level, and it is easy for students to form a fixed thinking mode, neglecting the cultivation of students' innovative thinking ability.

\subsection{The teacher's teaching method is single}

Many teachers have been exposed to the Internet for a short period of time, and have not yet fully understood and understood the new "Internet + Education" model. Coupled with the influence of traditional educational concepts, the teaching 
methods used by teachers in the teaching process are too single, and The information convenience and efficiency brought by "Internet +" are not fully utilized. This means that in addition to improving the true professional level, teachers should also learn and understand certain knowledge of Internet information technology, learn and understand the preferences of young students, and respond to the teaching methods according to the social development and the real learning demands of students Make certain adjustments.

\subsection{Lack of corresponding practical training in teaching}

Tourism management is an important branch of the management discipline. In the specific teaching process, students are not only required to have a solid basic theoretical knowledge, but also need to cultivate students' ability to solve practical problems. Therefore, the practical training link is essential. However, in actual teaching, many schools have incomplete training base equipment and staffing, difficulty in guaranteeing training expenditures, and too few teachers with professional double-teacher qualifications, so that there are few practical training links that can be carried out., Which greatly reduces the effectiveness of practical teaching. In addition, when conducting training and teaching, the setting of training topics did not closely follow the development of related industries, and the topics were old and could not truly reflect the goal of applicationoriented talent training.

\section{Relevant measures for the teaching reform of tourism management in colleges and universities under the "Internet +" environment}

\subsection{Improve teachers' information technology application ability}

In the "Internet +" environment, in order to improve the teaching quality of the tourism management major in colleges and universities, teachers should not only improve their professional capabilities, but also improve and exercise their information technology application capabilities. First of all, make changes in ideology, actively listen to new suggestions and ideas, and abandon traditional and old ideological and educational concepts. Secondly, learn information technology seriously in action, you can learn from colleagues, you can also learn from students, actively change, adapt, and hone the application of information technology in education through constant contact. Improve the actual teaching effect. Finally, return the main body of teaching to the students, actively communicate with students before the course teaching, understand the students' real knowledge demands, adjust the course content based on the students' feedback, and maximize the convenience brought by information technology.

\subsection{Diversified teaching methods}

Teachers of tourism management major should take the initiative to participate in various information technology training activities, enrich their own information teaching methods through continuous imitation and learning, and use diversified teaching methods to improve course teaching effects. The typical ones are recording micro-courses and live teaching through webcasting platforms. The former requires teachers to have a certain degree of video production ability, and focus on explaining a single problem within a limited time. Through the analysis and generalization of knowledge points, combined with exquisite and interesting video content to present, it greatly enhances students' interest in learning It is an effective way to improve the time utilization rate of students after class. The latter is more difficult than traditional classroom teaching. Teachers should not blindly explain the content of knowledge. They should also watch students' questions and interact with them in a timely manner, although they don't have to worry about classroom teaching. Discipline, but a variety of methods are needed to improve students' classroom participation and truly improve the efficiency of online classroom teaching.

\subsection{Pay attention to the design of practical teaching activities}

In the actual teaching process, practical activities play a very important role in the teaching of tourism management. Teachers should implement the teaching concept of "equal emphasis on learning and teaching" and design practical activities 
based on the actual development of related industries to ensure the effectiveness of practical activities. The use of Internet technology can help teachers quickly and accurately design practical teaching. First of all, before designing practical activities, teachers can not only prepare materials themselves, but also urge students to search for relevant materials, which can enrich the content of materials and cultivate students' independent learning ability. Second, use the convenience of Internet information to find the latest industry information, so that teachers can more accurately control the general direction of practical activities. Finally, teachers can use network communication software to actively communicate with students in their spare time, and combine students' ideas to finally establish practical teaching projects.

\section{Conclusion}

In the "Internet+" environment, with the application of new technologies and new concepts, it is not only an opportunity for college tourism management majors to improve the teaching quality, but also a huge test for the teaching level of college teachers. In addition to continuously improving and enhancing their own ability to use Internet information technology, teachers should also enrich their own teaching methods and pay attention to the design of practical teaching projects to enhance students' enthusiasm for learning and improve students' comprehensive practical ability.

\section{References}

1. Lu S. Research on the classroom teaching reform of tourism management under the background of "Internet+". Gao Xueju 2017; (12).

2. Fang X, Chen J. Analysis of the teaching reform ideas of the tourism management major in colleges and universitiesThe cultivation of applied talents under the background of "Internet +". Tourism Overview Monthly 2018; 275(07): $209+211$.

3. Wei M. Analysis of Classroom Teaching Reform in Tourism Management under the Background of "Internet + ". Intelligence 2019; (01): 180. 